\title{
SUBSTITUTION OF FAT WITH VARIOUS TYPES OF SQUASHES AND GOURDS FROM THE Cucurbitaceae FAMILY IN THE PRODUCTION OF LOW-FAT BUFFALO MEAT PATTIES
}

\author{
SITI NURJAWAHER SHAMSOL KAHAR ${ }^{1}$, MOHAMMAD RASHEDI ISMAIL-FITRY ${ }^{1 *}$, \\ MASNI MAT YUSOFF ${ }^{1}$, ASHARI ROZZAMRI ${ }^{1}$, JAMILAH BAKAR ${ }^{1}$ \\ and WAN ZUNAIRAH WAN IBADULLAH ${ }^{2}$ \\ ${ }^{1}$ Department of Food Technology, Faculty of Food Science and Technology, \\ Universiti Putra Malaysia, 43400, UPM Serdang, Selangor, Malaysia \\ ${ }^{2}$ Department of Food Science, Faculty of Food Science and Technology, \\ Universiti Putra Malaysia, 43400, UPM Serdang, Selangor, Malaysia \\ ${ }^{*}$ E-mail: ismailfitry@upm.edu.my
}

Accepted 18 May 2021, Published online 10 June 2021

\begin{abstract}
This study aimed to produce buffalo patties formulated with different types of squashes and gourds as fat substitutes. Kabocha squash, butternut squash, chayote squash, snake gourd and bottle gourd from the Cucurbitaceae family were used as the fat substitutes and buffalo meat patties with animal fat were the control. All patties were analysed and statistically compared in terms of physical properties and sensory acceptance. Generally, the moisture content, water holding capacity, cooking yield significantly increased for all samples compared to the control. The fat content reduced significantly below $3 \%$ for all fat-substituted patties, thus they can be regarded as low-fat. All fat-substituted samples were lighter in colour, with a harder texture than the control but the sensory analysis showed that the colour, texture, juiciness, flavour and overall acceptability of the fat-substituted patties were no different from the control. In conclusion, all the squashes and gourds tested were suitable as fat substitutes to produce low-fat buffalo patties, with chayote squash having the highest potential.
\end{abstract}

Key words: Buffalo meat products, fat mimetics, fat replacers, fat substitutes, pumpkins

\section{INTRODUCTION}

Meat and meat-based food products derived from domesticated animal species such as chicken, goat, cattle, pig, and to a lesser extent from buffalo, are normally consumed as sources of protein (Heinz \& Hautzinger, 2007). Buffalo meat is high in protein and low in fat and cholesterol, hence an ideal substitute for beef (Vasanthi et al., 2007). However, despite these benefits, meat products such as patties from buffalo meat still require an additional significant amount of fat and the excessive intake of these meat products is not recommended especially for certain population groups (Asgar et al., 2010). A high fat intake could increase the risk of obesity and some types of cancer, and saturated fat is associated with high blood cholesterol and coronary heart disease

\footnotetext{
* To whom correspondence should be addressed.
}

(Khalil, 2000; Yang et al., 2019). In addition, the intake of patties (burgers) showed quite high frequency among consumers (Tarmizi et al., 2020). These factors drive the demand for low-fat meat products possessing similar quality in terms of taste and appearance as the original high-fat products.

In an oil-in-water meat emulsion system, a network of water, protein and fat form a threedimensional gel matrix when heated (Owusu-Apenten, 2004). When carbohydrate-based ingredients such as starch are used to replace the fat, swelling occurs when water is added, with heat causing gelatinisation. Viscosity increases and a gel is formed thus mimicking the function of fat (Brewer, 2012). Fat substitutes using animal protein-based ingredients have good functional properties such as emulsion stability compared to animal fat, while the plantprotein-based ingredients have a more complex interaction in the emulsion system (Yashini et al., 
2019). When plant-based ingredients are mixed with meat-based protein, there can be co-aggregation of the proteins, gel and film formation, and stabilisation of emulsions and foams (Alves \& Tavares, 2019). Lipid-based ingredients from plants mostly possess properties similar to animal fat but healthier, however, modification to a structured oleogel is necessary to mimic the animal fat texture (Puşcaş et al., 2020). Generally, the fat substitutes imitate animal fat rheological properties by thickening the food matrix, mimicking the microstructure of the emulsified fat droplets, and replicating the oral properties (Kew et al., 2020). Nevertheless, these carbohydrate-, protein- or lipid-based ingredients may not imitate all the functional properties of the animal fat.

Plant-based ingredients in complex plant form (as puree or powder) can contain either carbohydrate, protein, lipid or all of them, so if used as a fat substitute could provide various functionalities similar to animal fat but also affect the final product properties such as the texture and sensory acceptance. Aslinah et al. (2018) used adzuki bean flour containing carbohydrate and protein as a partial fat substitute to produce low-fat meatballs. The cooking yield and moisture content were higher, but the meatballs were harder and less acceptable to consumers. Patinho et al. (2021) used Agaricus bisporus mushroom as partial fat replacer to produce beef patties, increasing the moisture content and yield, reducing the cooking loss and diameter reduction but the texture was less hard and chewy. Tabarestani and Tehrani (2014) optimised the use of soy flour, split-pea flour and wheat starch as partial fat substitutes for low-fat hamburgers, increasing the cooking yield, decreasing shrinkage and improving the texture.

Other potential groups of plants that can be used as fat substitutes are squashes and gourds from the Cucurbitaceae family that are similar to pumpkins (OECD, 2016). Sometimes pumpkins are also known as squash and vice versa based on the regions planted. The Cucurbitaceae family has a high water content (Gajera et al., 2017; Ugbaja et al, 2017; Vieira et al., 2019; Armesto et al., 2020), a good property for use as a fat substitute. Several studies showed that plants from the Cucurbitaceae family lower the fat content when incorporated into the food system. For example, mashed pumpkin used in making fish burgers resulted in higher moisture content but lower fat content (Ali et al., 2019). The quality of frankfurters was improved in terms of cooking loss, apparent viscosity, physicochemical properties, textural properties, and emulsion stability due to the use of pumpkin as a fat substitute (Kim et al., 2016). Verma et al. (2012) reported that adding bottle gourd to reduce the meat and fat in a chicken nugget formulation increased the $\mathrm{pH}$, moisture and dietary fibre content.
Nevertheless, different types of pumpkins/ squashes and gourds may impart different properties (Gajera et al., 2017; Ugbaja et al., 2017; de Almeida et al., 2019; Vieira et al., 2019) and their application as fat substitutes may contribute towards different meat product characteristics. Therefore, the objective of this study was to determine the physicochemical and sensory properties of buffalo patties formulated with five different types of squashes and gourds from the Cucurbitaceae family as fat substitutes. The outcome is expected to highlight the best squashes or gourds for use as fat substitutes, which could be applied in related industries or for further research.

\section{MATERIALS AND METHODS}

\section{Preparation of fat-substituted buffalo patties}

Five types of plants from the Cucurbitaceae family were used in this study, kabocha squash (Cucurbita maxima Duch), butternut squash (Cucurbita moschata Duchesne ex Poiret), chayote squash (Sechium Edule), snake gourd (Trichosanthes Cucumerina) and bottle gourd (Lagenaria Siceraria). The fruits of these plants were purchased from Econsave and Giant Hypermarket in Kamunting, Perak. The fruits were rinsed with clean water, peeled, cut into small pieces, boiled at $100^{\circ} \mathrm{C}$ for $10 \mathrm{~min}$ until soft, tossed and further ground into a puree using a blender (MX-900M Panasonic, Malaysia). Frozen sliced buffalo meat (top side) was purchased from Shahrul Fresh \& Frozen in Balakong, Selangor, while the beef fat was obtained from Kompleks Pasar Borong Selangor, Seri Kembangan, Selangor. The meats and fat were grounded separately using a mincer machine (Hobart 4822, USA). Sodium tripolyphosphate (STPP) and isolated soy protein (ISP) were from Meilun Food Chemical Sdn Bhd, Klang, Selangor and salt, sugar, garlic and ice were purchased from the local market at Seri Kembangan, Selangor.

The buffalo patties were formulated according to Table 1. Initially, the meat and other ingredients, except iced water and fat, were mixed for $5 \mathrm{~min}$ in a bowl cutter (K3 Model-Bench Type, Taiwan). Iced water was slowly added to the mixer and continuously mixed for another $5 \mathrm{~min}$, then the fat was added and mixed for another 10 min until the mixture homogenous. The mixture was transferred into a burger mould for shaping (70 $\mathrm{g}$ each) and stored in a freezer at $-18^{\circ} \mathrm{C}$. The sample with fat was termed as control buffalo patties (CBP). The fatsubstituted buffalo patties were produced using similar processing steps but with squashes and gourds to replace the fat. The fat-substituted buffalo patties were termed as kabocha squash buffalo patties (KSBP), butternut squash buffalo patties (BSBP), chayote squash buffalo patties (CSBP), 
Table 1. Formulations of the fat-substituted buffalo patties with squashes and gourds compared to the control with animal fat

\begin{tabular}{|c|c|c|c|c|c|c|c|}
\hline \multirow{2}{*}{ Ingredients } & \multirow{2}{*}{ Amount (\%) } & \multicolumn{5}{|c|}{ Amount $(\mathrm{g} / 733.33 \mathrm{~g})$} & \multirow[b]{2}{*}{ BGBP } \\
\hline & & CBP & KSBP & BSBP & CSBP & SGBP & \\
\hline Buffalo meat & 75.00 & 550.00 & 550.00 & 550.00 & 550.00 & 550.00 & 550.00 \\
\hline Fat & 15.00 & 110.00 & 0.00 & 0.00 & 0.00 & 0.00 & 0.00 \\
\hline Kabocha squash & - & - & 110.00 & - & - & - & - \\
\hline Butternut squash & - & - & - & 110.00 & - & - & - \\
\hline Chayote squash & - & - & - & - & 110.00 & - & - \\
\hline Snake gourd & - & - & - & - & - & 110.00 & - \\
\hline Bottle gourd & - & - & - & - & - & - & 110.00 \\
\hline Ice water & 4.40 & 32.27 & 32.27 & 32.27 & 32.27 & 32.27 & 32.27 \\
\hline Isolated Soy Protein (ISP) & 2.00 & 14.67 & 14.67 & 14.67 & 14.67 & 14.67 & 14.67 \\
\hline Salt & 1.50 & 11.00 & 11.00 & 11.00 & 11.00 & 11.00 & 11.00 \\
\hline Sugar & 1.00 & 7.33 & 7.33 & 7.33 & 7.33 & 7.33 & 7.33 \\
\hline Garlic & 0.70 & 5.13 & 5.13 & 5.13 & 5.13 & 5.13 & 5.13 \\
\hline STPP & 0.40 & 2.93 & 2.93 & 2.93 & 2.93 & 2.93 & 2.93 \\
\hline Total & 100.00 & 733.33 & 733.33 & 733.33 & 733.33 & 733.33 & 733.33 \\
\hline
\end{tabular}

CBP control buffalo patties; KSBP kabocha squash buffalo patties; BSBP butternut squash buffalo patties; CSBP chayote squash buffalo patties; SGBP snake gourd buffalo patties; $B G B P$ bottle gourd buffalo patties.

snake gourd buffalo patties (SGBP), and bottle gourd buffalo patties (BGBP). The buffalo patties were further analysed for their physicochemical and sensory properties.

\section{Proximate analysis}

The moisture, ash, protein, fat and carbohydrate contents were determined based on the AOAC (2000) method:

\section{Determination of moisture content}

The raw samples were weighed $(2-5 \mathrm{~g})$ in a crucible and put in the oven at $105^{\circ} \mathrm{C}$ for at least 7 hours. The formula shown below was used to calculate the moisture content:

Moisture $(\%)=\frac{(\text { Weight of sample }- \text { Dry weight of the sample })}{\text { Weight of sample }} \times 100 \%$

\section{Determination of ash content}

The raw samples were weighed $(3-5 \mathrm{~g})$ in a crucible and put in the muffle furnace at $550^{\circ} \mathrm{C}$ for at least 2 hours, then the ash was determined using the following formula:

$$
\operatorname{Ash}(\%)=\frac{(\text { Weight of ash }+ \text { Weight of crucibles })-(\text { Weight of crucible })}{\text { Weight of sample }} \times 100 \%
$$

\section{Determination of protein content}

The protein analysis was performed by digesting $2 \mathrm{~g}$ of each sample in a Kjeldahl flask, followed by distillation and titration steps. The protein content was calculated as follows:

Protein $(\%)=\%$ Nitrogen $\times 6.25$;

where 6.25 is the conversion factor.

\section{Determination of fat content}

The fat content was determined using a Soxhlet extractor with petroleum ether as the extracting solvent. The raw buffalo patties (2 g each) were transferred into a thimble and placed in the extractor. The flask containing the oil was weighed and dried in an oven $\left(105^{\circ} \mathrm{C}\right)$ for $15 \mathrm{~min}$ and the fat was analysed by calculating the oil content in the sample using the following formula:

$$
\text { Oil }(\%)=\frac{\text { Weight of oil }}{\text { Weight of sample }} \times 100
$$

\section{Water holding capacity (WHC)}

The WHC determination was conducted according to Dosh et al. (2016) with some modifications. Briefly, 10 grams of raw buffalo patties were mixed with $20 \mathrm{~g}$ of water and homogenised using a homogeniser (Heidolph Diax 900, USA), then centrifuged using a centrifuge (KUBOTA 5800, Japan) at 1500 r.p.m. for 5 min. The WHC of the sample was calculated as follows:

WHC $(\%)=\frac{(\text { Water weight before centrifuge })-(\text { Water weight after centrifuge })}{\text { (Sample weight })} \times 100 \%$

\section{Cooking yield}

The buffalo patties were cooked in a frying pan for 6 min on each side. The cooking yield was calculated based on the method described by Aslinah et al. (2018) as follows:

$$
\text { Cooking yield }(\%)=\frac{\text { Cooked weight of buffalo patty }}{\text { Raw weight of buffalo patty }} \times 100 \%
$$




\section{Shrinkage percentage}

The shrinkage percentage was calculated based on the method described by Darwish et al. (2012) as follows:

Shrinkage percentage $(\%)=$

(Raw thickness - Cooked thickness) + (Raw diameter - Cooked diameter (Raw thickness + Raw diameter)

\section{Determination of $\mathrm{pH}$ value}

The $\mathrm{pH}$ of the raw samples was measured in a homogenate prepared with a $10 \mathrm{~g}$ sample and distilled water $(100 \mathrm{~mL})$ using the ICM $41150 \mathrm{pH}$ meter (Darwish et al., 2012).

\section{Determination of colour}

The samples were evaluated in terms of lightness $\left(L^{*}\right)$, redness $\left(a^{*}\right)$, and yellowness $\left(b^{*}\right)$ using a chromameter CR-410 (Konica Minolta, Japan) (Aslinah et al., 2018).

\section{Determination of texture properties}

The textural properties of the buffalo patties were determined using a computer-assisted Stable Micro Systems Texture analyser (TA.XT2i-Plus, London). The hardness, cohesiveness, chewiness, springiness, and resilience of the sample were analysed. A $75 \mathrm{~mm}$ square compression platen type probe was used with a $25 \mathrm{~kg}$ load cell, with the pre-test speed set at 2.00 $\mathrm{mm} / \mathrm{s}$, test speed at $2.00 \mathrm{~mm} / \mathrm{s}$, the post-test speed at $5.00 \mathrm{~mm} / \mathrm{s}$, a distance of $10.000 \mathrm{~mm}$, and autotrigger type $(5.0 \mathrm{~g})$ following the method by Huda et al. (2010).

\section{Sensory evaluation}

The sensory evaluation was conducted using the acceptance test with a five-point hedonic scale ranging from 1 (dislike extremely) to 5 (like extremely) with some modifications (Adeyemi \& Olorunsanya, 2012). Warm buffalo patties were served to 30 untrained panellists and their acceptances in terms of aroma, colour, texture, chewiness, juiciness, flavour and overall acceptability of the samples were recorded

\section{Statistical analysis}

The experiments were performed in triplicate $(\mathrm{n}=3)$ except for sensory tests $(\mathrm{n}=30)$ and were analysed using one-way ANOVA and Tukey's test with a confidence level of $95 \%(p<0.05)$. Pearson correlation was also used to determine the correlation between selected parameters. All data were analysed using Minitab Statistical Software version 19 (MiniTab Inc., USA).

\section{RESULTS AND DISCUSSION}

\section{Proximate composition}

Table 2 shows the proximate composition of the buffalo patties produced with squashes and gourds as the fat substitute compared to the control. The fat-substituted buffalo patties had a higher moisture content compared to the control (70.08-72.94\% vs. $61.46 \% ; p<0.05)$ probably due to the high moisture content of raw kabocha squash $(87.60 \%)$, butternut squash $(91.20 \%)$, chayote squash $(94.00 \%)$, snake gourd $(94.60 \%)$ and bottle gourd $(96.10 \%)$ (Kim et al., 2005; Rahman et al., 2008; Viera et al., 2019; Armesto et al., 2020). Water can be used as a fat substitute, maintaining a high moisture content of the final meat product (Kumar et al., 2007), therefore the high moisture content of these squashes and gourds directly influenced the moisture of the fat-substituted buffalo patties. This is in agreement with the study by Zargar et al. (2014), which reported that the higher moisture content of pumpkins contributed to the higher moisture content of chicken sausages.

There was no significant difference in the ash values between SGBP (2.36\%), KSBP (2.18\%), and CSBP $(2.16 \%)$ but they were higher $(\mathrm{p}<0.05)$ than the other samples and control $(1.26-1.43 \%)$ in contrast to Rahman et al. (2008) who reported low ash values of varieties of squashes and gourds $(0.3-0.8 \%)$, possibly due to the different varieties and origin of these plants. The ash content in patties is usually contributed by spices, condiments (Ramadhan et al., 2011), and salt (Hsu \& Yu, 1999).

Table 2. The proximate composition of the fat-substituted buffalo patties with squashes and gourds compared to the control with animal fat

\begin{tabular}{lcccccc}
\hline \multirow{2}{*}{$\begin{array}{l}\text { Proximate composition } \\
\text { ( w/w) }\end{array}$} & \multicolumn{5}{c}{ Fat-substituted buffalo patties with squashes and gourds buffalo meat patties } \\
\cline { 2 - 6 } & CBP & KSBP & BSBP & CSBP & SGBP & BGBP \\
\hline Moisture content & $61.46 \pm 0.06^{\mathrm{d}}$ & $70.71 \pm 0.39^{\mathrm{bc}}$ & $70.08 \pm 0.69^{\mathrm{c}}$ & $72.11 \pm 0.70^{\mathrm{ab}}$ & $70.74 \pm 0.57^{\mathrm{bc}}$ & $72.94 \pm 0.44^{\mathrm{a}}$ \\
Ash content & $1.26 \pm 0.10^{\mathrm{b}}$ & $2.18 \pm 0.31^{\mathrm{a}}$ & $1.43 \pm 0.14^{\mathrm{b}}$ & $2.16 \pm 0.10^{\mathrm{a}}$ & $2.36 \pm 0.29^{\mathrm{a}}$ & $1.12 \pm 0.01^{\mathrm{b}}$ \\
Protein content & $12.34 \pm 0.34^{\mathrm{ab}}$ & $12.33 \pm 0.56^{\mathrm{ab}}$ & $11.72 \pm 0.61^{\mathrm{b}}$ & $12.83 \pm 0.70^{\mathrm{ab}}$ & $13.14 \pm 0.37^{\mathrm{a}}$ & $11.70 \pm 0.32^{\mathrm{b}}$ \\
Fat content & $7.90 \pm 0.43^{\mathrm{a}}$ & $2.05 \pm 0.47^{\mathrm{b}}$ & $1.94 \pm 0.50^{\mathrm{b}}$ & $0.70 \pm 0.33^{\mathrm{c}}$ & $0.82 \pm 0.07^{\mathrm{c}}$ & $1.61 \pm 0.24^{\mathrm{bc}}$ \\
\hline
\end{tabular}

Means $\pm S D$ that do not share the same letter are significantly different $(p<0.05)$ in the same row. CBP control buffalo patties; $K S B P$ kabocha squash buffalo patties; $B S B P$ butternut squash buffalo patties; CSBP chayote squash buffalo patties; SGBP snake gourd buffalo patties; $B G B P$ bottle gourd buffalo patties. 
Nevertheless, Ramadhan et al. (2011) reported that the ash content of different brands of Malaysian commercial meat patties was between $1.50-2.96 \%$, similar to the values recorded in the present study. Using the squashes and gourds as the fat substitute did not change the protein content compared to the control, probably due to the low protein content of the varieties of squashes and gourds tested (Rahman et al., 2008). Among all, SGBP had the highest value (13.14\%), which in agreement with Liyanage et al. (2016) who reported that the snake gourd has a high protein content, however, the protein values in the patties were still in the range observed in commercial chicken burgers (Ramadhan et al., 2011).

The use of squashes and gourds as fat substitutes significantly decreased $(p<0.05)$ the fat content of the buffalo patties $(0.70-2.05 \%)$ compared to the control $(7.90 \%)$. Varieties of raw squashes and gourds are well known for their low-fat content (0.1-0.3\%) (Rahman et al., 2008). This finding is in line with a report by Weiss et al. (2010), which stated that decreasing the fat content in meat products can be accomplished by adding more water and substituting the animal fat with plant sources. There was a negative correlation between the moisture content and fat content ( $p<0.05, r=-0.963)$, showing that the fat was successfully substituted by the squashes and gourds with high moisture content. Based on the Malaysian Food Act 1983 and Food Regulations 1985, a product can be claimed as lowfat if the fat content is not more than $3 \mathrm{~g}$ per $100 \mathrm{~g}$ of sample, therefore, these fat-substituted buffalo patties prepared with squashes and gourds can be claimed as low-fat buffalo patties.

\section{Water holding capacity (WHC), cooking yield, shrinkage and $\mathrm{pH}$}

It is apparent from Table 3 that almost all buffalo patties prepared with different squashes and gourds exhibited positive results in terms of WHC, cooking yield, shrinkage percentage and $\mathrm{pH}$. The CSBP, BGBP and BSBP exhibited a higher $(p<0.05)$ WHC compared to the other samples and control. Pumpkin (same family as squash and gourd) has been reported to improve the WHC of frankfurters due to the fibre content (Kim et al., 2016). This is supported by Méndez-Zamora et al. (2015), who reported that the addition of dietary fibre to the low-fat sausages contributed to a higher WHC. DeFreitas et al. (1997) stated that the WHC of the low-fat meat product is not due to the molecular interaction between the meat protein and the fat replacer, rather the ability of the protein network to trap water within the gelatinised emulsion. A high WHC is necessary to maintain the moisture content and juiciness of the meat product, therefore, adding squashes and gourds as fat substitutes had successfully increased the WHC in buffalo patties, particularly in CSBP, BGBP and BSBP.

Cooking yield is the final weight of the product after cooking, vice versa for cooking loss, which is referred to the weight loss after cooking but either can be used to predict the behaviour of the meat product during processing (Ulu, 2006). All the fatsubstituted buffalo patties possessed a higher $(p<$ $0.05)$ cooking yield compared to the control (57.59\%), with KSBP (66.30\%) and CSBP (65.62\%) having the highest values. The squashes and gourds were used as a fat substitute in puree form thus contained a high moisture (water) content (Table 2). The water may bind to the protein and carbohydrate during emulsification, therefore preventing water loss during cooking. This is supported by Shand (1997) who stated that when only water is used as a fat replacer, the meat product will shrink during cooking thus increasing the cooking loss, which can be prevented by adding carbohydrate and protein to bind with the water. There was a positive correlation between the moisture content and cooking yield ( $p<0.05, r=$ 0.869 ) to support this result. Similarly, Ali et al. (2019) reported that tilapia fish burgers containing mashed pumpkin had a higher cooking yield of $81.50 \%$ to $87.51 \%$. The cooking yield is based on moisture evaporation and dripping of the melted fat (Zargar et al., 2014) and as the moisture is trapped in the

Table 3. The water holding capacity, cooking yield, shrinkage and $\mathrm{pH}$ of the fat-substituted buffalo patties with squashes and gourds compared to the control with animal fat

\begin{tabular}{lcccccc}
\hline \multirow{2}{*}{ Properties } & \multicolumn{5}{c}{ Fat-substituted buffalo patties with squashes and gourds buffalo meat patties } \\
\cline { 2 - 7 } & \multicolumn{1}{c}{ CBP } & KSBP & BSBP & CSBP & SGBP & BGBP \\
\hline Water holding & $33.07 \pm 0.20^{\mathrm{b}}$ & $33.89 \pm 0.80^{\mathrm{b}}$ & $36.12 \pm 0.56^{\mathrm{a}}$ & $36.81 \pm 0.27^{\mathrm{a}}$ & $28.01 \pm 0.25^{\mathrm{c}}$ & $36.18 \pm 0.58^{\mathrm{a}}$ \\
capacity (\%) & & & & & & \\
Cooking yield (\%) & $57.59 \pm 0.52^{\mathrm{e}}$ & $66.30 \pm 0.50^{\mathrm{a}}$ & $62.97 \pm 0.09^{\mathrm{c}}$ & $65.62 \pm 0.48^{\mathrm{ab}}$ & $61.45 \pm 0.07^{\mathrm{d}}$ & $64.89 \pm 0.17^{\mathrm{b}}$ \\
Shrinkage (\%) & $30.17 \pm 0.26^{\mathrm{b}}$ & $30.56 \pm 0.46^{\mathrm{ab}}$ & $28.64 \pm 0.07^{\mathrm{c}}$ & $26.73 \pm 0.55^{\mathrm{d}}$ & $27.71 \pm 0.52^{\mathrm{cd}}$ & $31.54 \pm 0.48^{\mathrm{a}}$ \\
pH value & $6.12 \pm 0.09^{\mathrm{c}}$ & $6.47 \pm 0.05^{\mathrm{b}}$ & $7.75 \pm 0.09^{\mathrm{a}}$ & $6.28 \pm 0.07^{\mathrm{c}}$ & $6.51 \pm 0.06^{\mathrm{b}}$ & $6.23 \pm 0.03^{\mathrm{c}}$ \\
\hline
\end{tabular}

Means $\pm S D$ that do not share the same letter are significantly different $(p<0.05)$ in the same row. CBP control buffalo patties; $K S B P$ kabocha squash buffalo patties; $B S B P$ butternut squash buffalo patties; CSBP chayote squash buffalo patties; SGBP snake gourd buffalo patties; $B G B P$ bottle gourd buffalo patties. 
3-dimensional matrix and less fat is available, the cooking yield increases. Therefore, it can be concluded that substituting the fat with squashes and gourds can prevent more water loss from the patties.

Shrinkage is another important quality attribute for meat and meat products in the food industry (Barbera \& Tassone, 2006). Lower $(p<0.05)$ shrinkage values were observed for CSBP $(26.73 \%)$ and SGBP (27.71\%), indicating less water loss during cooking, whereas BGBP $(31.54 \%)$ and KSBP $(30.56 \%)$ had more shrinkage, although KBSP was no different to the control $(30.17 \%)$. The meat patties tend to shrink due to loss of water and fat during the cooking process (Ismail et al., 2021), which can be prevented by the substitution of the fat (Bastos et al., 2014). There was no difference in $\mathrm{pH}$ between the control (6.12), CSBP (6.28) and BGBP (6.23), while other samples exhibited higher $(p<0.05) \mathrm{pH}$ values. Pumpkin added to chicken products significantly decreased the $\mathrm{pH}$, which was attributed to the ascorbic acid content of the pumpkin (Verma et al., 2012; Zargar et al., 2014). Hence, the different $\mathrm{pH}$ values may be due to the wide range of ascorbic acid content found in the raw squashes and gourds (Rahman et al., 2008).

\section{Colour and texture profile analysis (TPA)}

Table 4 displays the colour and texture profile of the buffalo patties with various squashes and gourds as fat substitutes. The primary factor influencing consumers' acceptability of buffalo patties is their colour and appearance. According to Ikhlas et al. (2011), the colour trait of cooked meat products is affected by the additives used in the formulation and the pigmentation of the meat. Figure 1 shows the comparison of the control and the fat-substituted buffalo patties. In terms of lightness ( $L^{*}$ value), all samples were lighter $(p<0.05)$ than the control, with KSBP exhibiting the highest value (47.06). There was a negative correlation between the lightness and fat content ( $p<0.05, r=-0.843$ ), supporting this finding. The redness ( $a *$ value) of KSBP (6.80), BSBP (6.75), and BGBP (6.63) was also significantly higher $(p<0.05)$ than the control (5.29). Cengiz and Gokoglu (2007) also reported an increase in the redness of meat products as the fat content decreased. In contrast, all buffalo patties varied in yellowness $\left(b^{*}\right.$ value), with no difference observed between the control (14.16), CSBP (14.85) and BGBP (15.87), whereas KSBP, BSBP and SGBP exhibited higher $b^{*}$ values (18.06, 16.97 and 16.41, respectively). The yellowness of the patties is probably due to the bright yellow-orange colour of the flesh of the squashes and gourds. Furthermore, pumpkins were reported to retain their colour saturation on air-drying at $30^{\circ} \mathrm{C}$ to $70^{\circ} \mathrm{C}$ (Guiné and Barroca, 2012).

Regarding texture, all the fat-substituted buffalo patties had similar hardness $(11.35-13.21 \mathrm{~kg})$ but were harder than the control $(8.68 \mathrm{~kg} ; p<0.05)$. Animal fat contributes to the tenderness of meat product, so if the fat is removed, the products may become drier and harder, especially if substituted with ingredients with a high fibre content (Newman, 1993). This is supported by the negative correlation between the hardness and the fat content $(p<0.05$, $r=-0.936)$, indicating that the fat plays an important role in meat product tenderness. However, the firmness values were acceptable and within the range of Malaysian commercial chicken burgers $(8.00 \mathrm{~kg}$ to $19.04 \mathrm{~kg}$ ) (Ramadhan et al., 2011). In contrast, Verma et al. (2012) reported a decrease in the hardness of low-fat chicken nuggets prepared using bottle gourd as the fat substitute.

Furthermore, there was no significant difference between the patties in terms of springiness $(0.86-0.92 \mathrm{~mm})$, resilience $(0.34-0.42)$ and cohesiveness (0.75-0.78), except for SGBP with significantly high cohesiveness (0.82). Commercial chicken burgers have a lower range of springiness $(0.141-0.443 \mathrm{~mm})$ and cohesiveness $(0.223-0.371)$

Table 4. The colour $\left(L^{*}, a^{*}, b^{*}\right)$ and texture profiles of the fat-substituted buffalo patties with squashes and gourds compared to the control with animal fat

\begin{tabular}{|c|c|c|c|c|c|c|}
\hline \multirow{2}{*}{ Properties } & \multicolumn{6}{|c|}{ Fat-substituted buffalo patties with squashes and gourds buffalo meat patties } \\
\hline & $\mathrm{CBP}$ & KSBP & BSBP & CSBP & SGBP & BGBP \\
\hline$L^{*}$ & $37.07 \pm 0.91^{d}$ & $47.06 \pm 0.42^{\mathrm{a}}$ & $45.52 \pm 0.55^{\mathrm{ab}}$ & $45.85 \pm 0.33^{\mathrm{ab}}$ & $42.53 \pm 0.54^{c}$ & $45.27 \pm 0.64^{b}$ \\
\hline$a^{*}$ & $5.29 \pm 0.40^{b}$ & $6.80 \pm 0.29 a$ & $6.75 \pm 0.40^{\mathrm{a}}$ & $6.20 \pm 0.23^{\mathrm{ab}}$ & $5.89 \pm 0.73^{a b}$ & $6.63 \pm 0.19^{a}$ \\
\hline$b^{*}$ & $14.16 \pm 0.68^{d}$ & $18.06 \pm 1.02^{\mathrm{a}}$ & $16.97 \pm 0.69^{a b}$ & $14.85 \pm 0.45^{\mathrm{cd}}$ & $16.41 \pm 0.25^{\mathrm{abc}}$ & $15.87 \pm 0.99 \mathrm{bcd}$ \\
\hline Hardness (kg) & $8.68 \pm 0.28^{b}$ & $11.35 \pm 0.07^{a}$ & $11.44 \pm 0.33^{a}$ & $13.10 \pm 1.58^{a}$ & $12.87 \pm 1.21^{\mathrm{a}}$ & $13.21 \pm 0.10^{a}$ \\
\hline Springiness (mm) & $0.87 \pm 0.01^{a}$ & $0.86 \pm 0.01^{\mathrm{a}}$ & $0.89 \pm 0.02^{a}$ & $0.88 \pm 0.01^{a}$ & $0.92 \pm 0.01^{a}$ & $0.91 \pm 0.06^{a}$ \\
\hline Cohesiveness & $0.75 \pm 0.01^{b}$ & $0.77 \pm 0.01^{b}$ & $0.78 \pm 0.01^{\mathrm{b}}$ & $0.78 \pm 0.02^{\mathrm{b}}$ & $0.82 \pm 0.03^{a}$ & $0.77 \pm 0.01^{b}$ \\
\hline Chewiness (kg.mm) & $6.41 \pm 0.31^{c}$ & $8.36 \pm 0.32^{\mathrm{ab}}$ & $8.45 \pm 0.73^{\mathrm{ab}}$ & $7.24 \pm 0.76^{b c}$ & $9.73 \pm 0.90^{a}$ & $9.48 \pm 0.45^{a}$ \\
\hline Resilience & $0.34 \pm 0.01^{b}$ & $0.35 \pm 0.01 \mathrm{ab}$ & $0.37 \pm 0.01^{\mathrm{ab}}$ & $0.38 \pm 0.01^{\mathrm{ab}}$ & $0.42 \pm 0.06^{b}$ & $0.35 \pm 0.01^{\mathrm{ab}}$ \\
\hline
\end{tabular}

Means \pm SD that do not share the same letter are significantly different $(p<0.05)$ in the same row. CBP control buffalo patties; $K S B P$ kabocha squash buffalo patties; $B S B P$ butternut squash buffalo patties; CSBP chayote squash buffalo patties; SGBP snake gourd buffalo patties; $B G B P$ bottle gourd buffalo patties. 


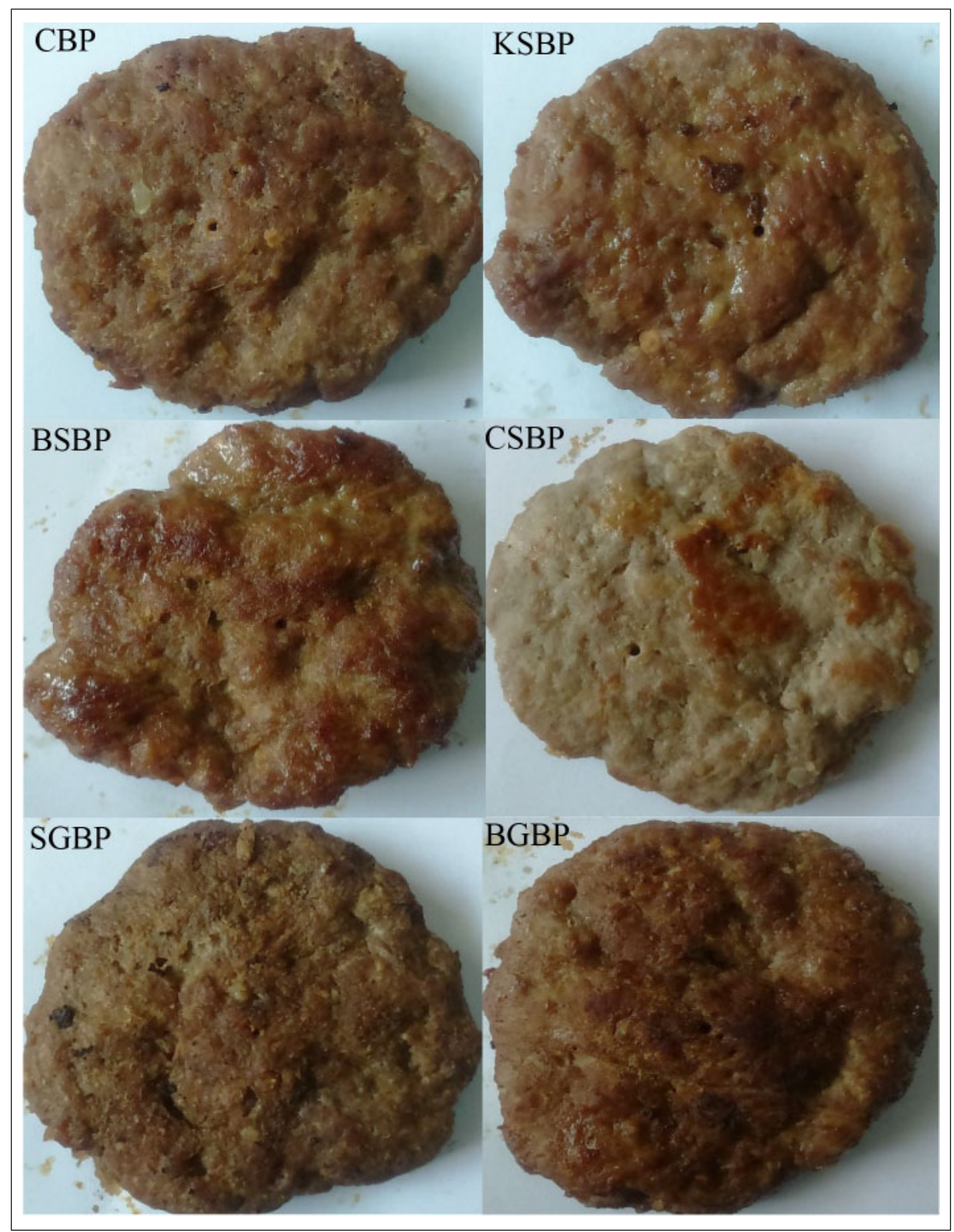

Fig. 1. The fat-substituted buffalo patties with squashes and gourds compared to the control with animal fat. CBP, control buffalo patties; KSBP, kabocha squash buffalo patties; BSBP, butternut squash buffalo patties; CSBP, chayote squash buffalo patties; SGBP, snake gourd buffalo patties; BGBP, bottle gourd buffalo patties. 
Table 5. Sensory properties of the fat-substituted buffalo patties with squashes and gourds compared to the control with animal fat

\begin{tabular}{lcccccc}
\hline \multirow{2}{*}{ Sensory properties } & \multicolumn{5}{c}{ Fat-substituted buffalo patties with squashes and gourds buffalo meat patties } \\
\cline { 2 - 6 } & \multicolumn{1}{c}{ CBP } & KSBP & BSBP & CSBP & SGBP & BGBP \\
\hline Aroma & $4.97 \pm 0.18^{\mathrm{c}}$ & $4.63 \pm 0.76^{\mathrm{bc}}$ & $3.70 \pm 1.34^{\mathrm{a}}$ & $4.10 \pm 1.21^{\mathrm{b}}$ & $4.53 \pm 0.86^{\mathrm{c}}$ & $4.53 \pm 0.78^{\mathrm{bc}}$ \\
Colour & $3.13 \pm 1.11^{\mathrm{a}}$ & $3.57 \pm 1.07^{\mathrm{a}}$ & $3.13 \pm 1.01^{\mathrm{a}}$ & $3.37 \pm 0.96^{\mathrm{a}}$ & $3.40 \pm 1.10^{\mathrm{a}}$ & $3.53 \pm 1.01^{\mathrm{a}}$ \\
Texture & $3.23 \pm 1.07^{\mathrm{a}}$ & $3.63 \pm 1.03^{\mathrm{a}}$ & $3.50 \pm 1.01^{\mathrm{a}}$ & $3.17 \pm 1.12^{\mathrm{a}}$ & $3.63 \pm 0.85^{\mathrm{a}}$ & $3.60 \pm 0.93^{\mathrm{a}}$ \\
Chewiness & $4.03 \pm 0.72^{\mathrm{a}}$ & $4.77 \pm 0.43^{\mathrm{b}}$ & $4.47 \pm 0.68^{\mathrm{b}}$ & $4.80 \pm 0.41^{\mathrm{b}}$ & $4.53 \pm 0.57^{\mathrm{b}}$ & $4.63 \pm 0.49^{\mathrm{b}}$ \\
Juiciness & $3.03 \pm 1.22^{\mathrm{a}}$ & $3.60 \pm 0.86^{\mathrm{a}}$ & $3.20 \pm 1.00^{\mathrm{a}}$ & $3.60 \pm 0.86^{\mathrm{a}}$ & $3.37 \pm 0.76^{\mathrm{a}}$ & $3.50 \pm 0.73^{\mathrm{a}}$ \\
Flavour & $4.13 \pm 0.57^{\mathrm{a}}$ & $4.00 \pm 0.98^{\mathrm{a}}$ & $3.57 \pm 0.90^{\mathrm{a}}$ & $4.03 \pm 0.85^{\mathrm{a}}$ & $4.10 \pm 0.40^{\mathrm{a}}$ & $3.80 \pm 0.76^{\mathrm{a}}$ \\
Overall & $3.43 \pm 1.17^{\mathrm{a}}$ & $3.37 \pm 1.16^{\mathrm{a}}$ & $2.87 \pm 0.82^{\mathrm{a}}$ & $3.33 \pm 1.09^{\mathrm{a}}$ & $3.43 \pm 0.63^{\mathrm{a}}$ & $3.40 \pm 0.62^{\mathrm{a}}$ \\
\hline
\end{tabular}

Means \pm SD that do not share the same letter are significantly different $(p<0.05)$ in the same row. CBP control buffalo patties; $K S B P$ kabocha squash buffalo patties; BSBP butternut squash buffalo patties; CSBP chayote squash buffalo patties; SGBP snake gourd buffalo patties; $B G B P$ bottle gourd buffalo patties. 1- dislike extremely, 2- dislike moderately, 3- neither like nor dislike, 4- like moderately, 5- like extremely.

(Ramadhan et al., 2011), which significantly influenced by phosphates, salt, and water added during processing (Huda et al., 2010). There was no significant difference in terms of chewiness between the control $(6.41 \mathrm{~kg} / \mathrm{mm})$ and CSBP $(7.24 \mathrm{~kg} / \mathrm{mm})$, and these samples were significantly less chewy compared to other patties $(8.36-9.73 \mathrm{~kg} / \mathrm{mm})$. Several factors are responsible for the textural properties of comminuted meat products including the degree of stromal protein content, myofibrillar proteins extracted, and the non-meat ingredients added such as salt, sugar phosphate and water. The sensory test should be performed together with TPA to determine the acceptable textural properties of meat products among consumers.

\section{Sensory evaluation}

The sensory properties of the buffalo patties are summarised in Table 5. In the study by Hawashin et al. (2016), the consumers' acceptability of beef patties was influenced by several sensory attributes including appearance, tenderness, taste, flavour, juiciness and overall acceptability. With reference to Table 5, there was no significant difference between the patties in terms of sensory acceptability of their colour, texture, juiciness and flavour. The acceptance levels of these parameters of the fat-substituted buffalo patties with squashes and gourds were between "like moderately" to "like extremely". Also, the chewiness of the fat-substituted buffalo patties was more acceptable to the panellists compared to the control. In terms of aroma, all the fat-substituted buffalo patties with squashes and gourds were similarly acceptable compared to the control, except for BSBP and CSBP, which were categorised as "like extremely" and "like moderately", respectively. There was no difference in the overall acceptability of the fat-substituted patties and control, with the only BSBP classified as "neither like nor dislike", probably due to the influence of the aroma score. In conclusion, the panellists could not differentiate between the characteristics of the fat-substituted buffalo patties with squashes and gourds and the control with fat, thereby supporting the use of squashes and gourds as fat substitutes without jeopardising the sensory properties of the newly formulated product.

\section{CONCLUSION}

Generally, all type of squashes and gourds from the Cucurbitaceae family used in this study are suitable for the preparation of low-fat buffalo patties. However, the superior water holding capacity, cooking yield and shrinkage results of the patties made with chayote squash make it a better fat substitute. The redness and yellowness of fatsubstituted buffalo patties with chayote squash, as well as the springiness, cohesiveness, chewiness, and resilience were similar to the control and the panellists preferred chayote squash as a fat substitute in buffalo patties in terms of chewiness compared to other samples. More importantly, the newly formulated buffalo patties with chayote squash as a fat substitute can be claimed as low-fat with the lowest fat content of $0.70 \%$ of all samples. In conclusion, squashes and gourds, particularly chayote squash, are potential fat substitutes for the production of low-fat buffalo patties.

\section{ACKNOWLEDGEMENT}

This work was supported by the Faculty of Food Science and Technology, Universiti Putra Malaysia and the Ministry of Higher Education of Malaysia (FRGS/1/2019/STG04/UPM/02/7). 


\section{REFERENCES}

Adeyemi, K.D. \& Olorunsanya, A.O. 2012. Effect of tomato (Lycopersicon esculentum) powder on oxidative stability and sensory characteristics of broiler meat. African Journal of Food, Agriculture, Nutrition and Development, 12(6): 6794-6808.

Ali, H.A., Mansour, E.H., E-lBedawey, A.E.F.A. \& Osheba, A.S. 2019. Evaluation of tilapia fish burgers as affected by different replacement levels of mashed pumpkin or mashed potato. Journal of the Saudi Society of Agricultural Sciences, 18(2): 127-132.

Alves, A.C. \& Tavares, G.M. 2019. Mixing animal and plant proteins: Is this a way to improve protein techno-functionalities?. Food Hydrocolloids, 97: 105171.

Association of Official Analytical Chemists (AOAC). 2000. Official Methods of Analysis of the Association of Official Analytical Chemists. Association of Official Analytical Chemists, Washington.

Armesto, J., Rocchetti, G., Senizza, B., Pateiro, M., Barba, F.J., Domínguez, R., Lucini L. \& Lorenzo, J.M. 2020. Nutritional characterization of Butternut squash (Cucurbita moschata D.): Effect of variety (Ariel vs. Pluto) and farming type (conventional vs. organic). Food Research International, 132: 1-9.

Asgar, M.A., Fazilah, A., Huda, N., Bhat, R., Karim, A.A. 2010. Nonmeat protein alternatives as meat extenders and meat analogs. Comprehensive Reviews in Food Science and Food Safety, 9(5): 513-529.

Aslinah, L.N.F., Yusoff, M.M. \& Ismail-Fitry, M.R. 2018. Simultaneous use of adzuki beans (Vigna angularis) flour as meat extender and fat replacer in reduced-fat beef meatballs (bebola daging). Journal of Food Science and Technology, 55(8): 3241-3248.

Barbera, S. \& Tassone, S. 2006. Meat cooking shrinkage: Measurement of a new meat quality parameter. Meat Science, 73(3): 467-474.

Bastos, S.C., Pimenta, M.E.S., Pimenta, C.J., Reis, T.A., Nunes, C.A., Pinheiro, A.C.M., Fabrício L.F.F. \& Leal., R.S. 2014. Alternative fat substitutes for beef burger: technological and sensory characteristics. Journal of Food Science and Technology, 51(9): 2046-2053.

Brewer, M.S. 2012. Reducing the fat content in ground beef without sacrificing quality: A review. Meat Science, 91(4): 385-395.

Cengiz, E. \& Gokoglu, N. 2007. Effects of fat reduction and fat replacer addition on some quality characteristics of frankfurter type sausages. International Journal of Food Science \& Technology, 42(3): 366-372.
Darwish, S.M.I., El-Geddawy, M.A.H., Khalifa, R.M.B. \& Mohamed, R.A.A. 2012. Physicochemical changes of frozen chicken burger formulated with some spices and herbs. Frontiers in Science, 2(6): 192-199.

de Almeida, A.B., de Lima, T.M., de Oliveira Filho, J.G., Santana, R.V., Lima, D.S., Moreira, E.A. \& Egea, M.B. 2019. Relation between physicochemical characteristics and sensory profiles of cooked pumpkin varieties. Emirates Journal of Food and Agriculture, 31(9): 697-707.

DeFreitas, Z., Sebranek, J.G., Olson, D.G. \& Carr, J.M. 1997. Carrageenan effects on salt soluble meat proteins in model systems. Journal of Food Science, 62(3): 539-543.

Dosh, K.S., Tawfiq, N.N. \& Jabbar, S.H. 2016. Preparation of modified chicken burger by partial replacement of chicken meat with powdered of oyster mushroom and study it is physical and sensory properties. Iraqi Journal of Agricultural Sciences, 47(7): 138-143.

Gajera, R.R., Joshi, D.C. \& Ravani, A. 2017. Processing potential of bottle gourd ( $L$. siceraria) Fruits: An overview. International Journal of Herbal Medicine, 5(4): 106-109.

Guiné, R.P. \& Barroca, M.J. 2012. Effect of drying treatments on texture and color of vegetables (pumpkin and green pepper). Food and Bioproducts Processing, 90(1): 58-63.

Hawashin, M.D., Al-Juhaimi, F., Ahmed, I.A.M., Ghafoor, K. \& Babiker, E.E. 2016. Physicochemical, microbiological and sensory evaluation of beef patties incorporated with destoned olive cake powder. Meat Science, 122: 32-39.

Heinz, G. \& Hautzinger, P. 2007. Meat processing technology. For small-to medium scale producers: Food and Agriculture Organization of the United Nations Regional Office for Asia and the Pacific. URL http://www.fao.org/3/ai407e/ai407e00.pdf. (accessed 03.01.2020).

Hsu, S.Y. \& Yu, S.H. 1999. Effects of phosphate, water, fat and salt on qualities of low-fat emulsified meatball. Journal of Food Engineering, 39(2): 123-130.

Huda, N., Shen, Y.H., Huey, Y.L., Ahmad, R. \& Mardiah, A. 2010. Evaluation of physicochemical properties of Malaysian commercial beef meatballs. American Journal of Food Technology, 5(1): 13-21.

Ikhlas, B., Huda, N. \& Noryati, I. 2011. Chemical composition and physicochemical properties of meatballs prepared from mechanically deboned quail meat using various types of flour. International Journal of Poultry Science, 10(1): 3037.

Ismail, M.A., Chong, G.H. \& Ismail-Fitry, M.R. 2021. Comparison of the microstructural, physicochemical and sensorial properties of buffalo meat 
patties produced using bowl cutter, universal mixer and meat mixer. Journal of Food Science and Technology, 1-8.

Kew, B., Holmes, M., Stieger, M. \& Sarkar, A. 2020. Review on fat replacement using protein-based microparticulated powders or microgels: A textural perspective. Trends in Food Science \& Technology, 106: 457-468.

Khalil, A.H. 2000. Quality characteristics of low-fat beef patties formulated with modified corn starch and water. Food Chemistry, 68(1): 61-68.

Kim, S.R., Ha, T.Y., Song, H.N., Kim, Y.S. \& Park, Y.K. 2005. Comparison of nutritional composition and antioxidative activity for kabocha squash and pumpkin. Korean Journal of Food Science and Technology, 37(2): 171-177.

Kim, C.J., Kim, H.W., Hwang, K.E., Song, D.H., Ham, Y.K., Choi, J.H., Kim, Y.B. \& Choi, Y.S. 2016. Effects of dietary fiber extracted from pumpkin (Cucurbita maxima Duch.) on the physicochemical and sensory characteristics of reducedfat frankfurters. Korean Journal for Food Science of Animal Resources, 36(3): 309-318.

Kumar, M., Sharma, B.D. \& Kumar, R.R. 2007. Evaluation of sodium alignate as a fat replacer on processing and shelf-life of low-fat ground pork patties. Asian-Australasian Journal of Animal Sciences, 20(4): 588-597.

Liyanage, R., Nadeeshani, H., Jayathilake, C., Visvanathan, R. \& Wimalasiri, S. 2016. Comparative Analysis of Nutritional and Bioactive Properties of Aerial Parts of Snake Gourd (Trichosanthes cucumerina Linn.). International Journal of Food Science, 2016: 1-7.

Méndez-Zamora, G., García-Macías, J.A., SantellanoEstrada, E., Chávez-Martínez, A., DuránMeléndez, L.A., Silva-Vázquez, R. \& QuinteroRamos, A. 2015. Fat reduction in the formulation of frankfurter sausages using inulin and pectin. Food Science and Technology, 35(1): 25-31.

Newman, P.B. 1993. An overview of the role of fat in nutrition and formulation and its measurement in the live animal, meat carcass and processed meat products. Food Structure, 12(4): 443-455.

OECD, 2016. "Squashes, pumpkins, zucchinis and gourds (Cucurbita species)", in Safety Assessment of Transgenic Organisms in the Environment, Volume 5. OECD Consensus Documents, OECD Publishing, Paris.

Owusu-Apenten, R.K. 2004. Testing protein functionality. In: Proteins in Food Processing. R.Y. Yada (Ed.). Woodhead Publishing Limited, Cambridge. pp. 217-244.

Patinho, I., Selani, M.M., Saldaña, E., Bortoluzzi, A.C.T., Rios-Mera, J.D., da Silva, C.M., Kushida, M.M. \& Contreras-Castillo, C.J. 2021. Agaricus bisporus mushroom as partial fat replacer improves the sensory quality maintaining the instrumental characteristics of beef burger. Meat Science, 172: 108307.

Puşcaş, A., Mure'an, V., Socaciu, C. \& Muste, S. 2020. Oleogels in food: a review of current and potential applications. Foods, 9(1): 70.

Rahman, A.H.M.M., Anisuzzaman, M., Ahmed, F., Islam, A.K.M.R. \& Naderuzzaman, A.T.M. 2008. Study of nutritive value and medicinal uses of cultivated cucurbits. Journal of Applied Sciences Research, 4(5): 555-558.

Ramadhan, K., Huda, N. \& Ahmad, R. 2011. Physicochemical characteristics and sensory properties of selected Malaysian commercial chicken burgers. International Food Research Journal, 18(4): 1349-1357.

Shand, P.J. 1997. Mimetic and synthetic fat replacers for the meat industry. In: Production and Processing of Healthy Meat, Poultry and Fish Products. A.M. Pearson and T.R. Dutson (Eds.). Chapman \& Hall, London. pp. 191-209.

Tabarestani, H.S. \& Tehrani, M.M. 2014. Optimization of physicochemical properties of low fat hamburger formulation using blend of soy flour, split pea flour and wheat starch as part of fat replacer system. Journal of Food Processing and Preservation, 38(1): 278-288.

Tarmizi, S.F.M., Daud, N.M. \& Rahman, H.A. 2020. Malaysian ready-to-eat cooked dishes: consumption patterns among adults and nutrient composition of selected highly consumed dishes. Malaysian Applied Biology, 49(5): 6170.

Ugbaja, C.C., Fawibe, O.O., Oyelakin, A.S., Fadimu, I.O., Ajiboye, A.A. \& Agboola, D.A. 2017. Comparative phytochemical and nutritional composition of trichosanthes cucumerina (L.) and some Solanum lycopersicum (L.) cultivars in Nigeria. American Journal of Plant Sciences, 8(2): 297-309.

Ulu, H. 2006. Effects of carrageenan and guar gum on the cooking and textual properties of low fat meatballs. Food Chemistry, 95(4): 600-605.

Vasanthi, C., Venkataramanujam, V. \& Dushyanthan, K. 2007. Effect of cooking temperature and time on the physico-chemical, histological and sensory properties of female carabeef (buffalo) meat. Meat Science, 76(2): 274-280.

Verma, A.K., Sharma, B.D. \& Banerjee, R. 2012. Quality characteristics of low fat chicken nuggets: effect of common salt replacement and added bottle gourd (Lagenaria siceraria L.). Journal of the Science of Food and Agriculture, 92(9): 1848-1854.

Vieira, E.F., Pinho, O., Ferreira, I.M. \& Delerue-Matos, C. 2019. Chayote (Sechium edule): A review of nutritional composition, bioactivities and potential applications. Food Chemistry, 275: 557-568. 
Weiss, J., Gibis, M., Schuh, V. \& Salminen, H. 2010. Advances in ingredient and processing systems for meat and meat products. Meat Science, 86(1): 196-213.

Yang, J.J., Yu, D., Takata, Y., Smith-Warner, S.A., Blot, W., White, E., Robien, K., Park, Y., Xiang, Y.B., Sinha, R. \& Lazovich, D. 2017. Dietary fat intake and lung cancer risk: a pooled analysis. Journal of Clinical Oncology, 35(26): 3055 3064.
Yashini, M., Sunil, C.K., Sahana, S., Hemanth, S.D., Chidanand, D. \& Rawson, A. 2019. Protein-based Fat Replacers - A Review of Recent Advances. Food Reviews International, 37(2): 197-223.

Zargar, F.A., Kumar, S., Bhat, Z.F. \& Kumar, P. 2014. Effect of pumpkin on the quality characteristics and storage quality of aerobically packaged chicken sausages. SpringerPlus, 3(39): 1-10. 
